\title{
NITROUS OXIDE ADMINISTRATION IN THE PRESENCE OF SUBCUTANEOUS EMPHYSEMA: AN EXPERIMENTAL MODEL
}

\author{
Thomas J. Poulton, Larky W. Haldeman, and Edwin S. Munson
}

\begin{abstract}
Adverse effects may occur when patients with air in the pleural space or in the cerebral ventricles breathe nitrous oxide. We developed an animal model to learn whether similar adverse effects are associated with the inhalation of nitrous oxide when air is present in the subcutaneous space. We induced extensive subcutaneous emphysema in swine and measured oxygen and carbon dioxide tensions in systemic arterial and mixed venous blood; cardiac output; intravascular, airway, and pre-stemal subcutaneous pressures; total pulmonary-thoracic static compliance; and thoracic girth before and after a 45 minute period of breathing 75 per cent nitrous oxide in oxygen. Cardiac output decreased from 3.13 $\pm 0.51 \mathrm{l} / \mathrm{min}$ to $2.40 \pm 0.62 \mathrm{l} / \mathrm{min}(\mathrm{p}<0.05)$; no other values changed significantly. No significant adverse cardiorespiratory effects resulted from the transfer of inhaled nitrous oxide to the subcutaneous space in this animal model.
\end{abstract}

Key Words: Anaesthetics, Gases, nitrous oxide; Complications, subcutaneous emphysema.

AlTHOUGH air-filled cavities in the body tend to decrease in size and to disappear spontaneously, during the inhalation of nitrous oxide the spaces increase in size until an equilibrium occurs. ${ }^{1}$ This phenomenon occurs because of the difference between the solubilities of nitrous oxide and of nitrogen in blood. The transfer of nitrous oxide into air within the pleural space $^{2,3}$ or the cerebral ventricles ${ }^{4}$ may produce tension pneumothorax or pneumocephalus, respectively. In 1974, Munson hypothesized that, because of this phenomenon, nitrous oxide would also adversely affect patients with mediastinal or subcutaneous emphysema. ${ }^{1}$ Later, Rosenberg et $a l^{5}$ and Milne et al. ${ }^{6}$ similarly recommended that nitrous oxide not be used for patients with subcutaneous emphysema. To test this hypothesis we studied the cardiorespiratory changes

Thomas J. Poulton, M.D., Assistant Professor, Presently Associate Professor, Department of Anesthesiology, The Creighton University School of Medicine, Omaha, Nebraska; Larry W. Haldeman, M.D., Fellow, Pulmonary Medicine and Christmas Seal Fellow of the Florida Lung Association. Presently: in private medical practice in Marietta, Georgia; Edwin S. Munson, M.D., Professor of Anaesthesiology. Received from the Department of Anaesthesiology and the Division of Pulmonary Medicine, College of Medicine, University of Florida, Gainesville, Florida 32610 .

Address correspondence and reprint requests to Dr. T.J. Poulton, Department of Anesthesiology, The Creighton University School of Medicine, 601 North 30th Street, Omaha, Nebraska 68131, U.S.A. 435 induced by nitrous oxide in swine with subcutaneous emphysema.

\section{Methods}

Ten young swine weighing $20-25 \mathrm{~kg}$ were anaesthetized with intramuscular ketamine hydrochloride $20 \mathrm{mg} \cdot \mathrm{kg}^{-1}$. A catheter for the administration of fluids and drugs was inserted into a vein of the ear, the trachea was intubated and anaesthesia and immobilization were maintained with intravenous thiamylal and pancuronium bromide. The lungs were ventilated with air from a time-cycled volume ventilator, maintaining $\mathrm{Paco}_{2}$ between 4.9 and $5.7 \mathrm{kPa}$ (37 and 43 torr). Body temperature was monitored by a pulmonary artery thermistor and was maintained at $37.0 \pm 1{ }^{\circ} \mathrm{C}$ by external infrared heating. A Swan-Ganz ${ }^{\infty}$ thermodilution catheter was placed into the pulmonary artery through a high cervical jugular venous cutdown. Each animal received lactated Ringer's solution, $2-3 \mathrm{ml} \cdot \mathrm{kg}^{-1} /$ hour to maintain hydration.

An 18-gauge Teflon catheter was placed surgically into the carotid artery and a 12-gauge plastic catheter was placed into the subcutaneous tissue anterior to the sternum. Pressures from the arterial and central venous catheters, from the subcutaneous space and from the airway were transduced with a high fidelity pressure measurement (Bentley Laboratories, Inc., Irvine,

Can. Anaesth. Soc. J., vol. 29, no. 5, Septembu: 1982 
California) and recording system (Grass Medical Instruments, Quincy, Massachusetts).

Blood samples and measurements were obtained as follows: sampling of systemic and mixed venous (pulmonary arterial) blood for analysis of oxygen and carbon dioxide tensions; measurement of cardiac output (in triplicate) by the technique of thermodilution; measurement of vascular, pre-sternal subcutaneous and airway pressures during three consecutive respiratory cycles; determination of total pulmonarythoracic static compliance at three different volumes (functional residual capacity plus 250 , 500 and $750 \mathrm{ml}$ respectively) by means of a "super syringe"; and measurement of thoracic girth at mid-sternum. Pulmonary shunt fraction (Q́sp/Qt) was calculated using the equation

$$
\dot{\mathrm{Q} p} / \dot{\mathrm{Q}} \mathrm{t}=\frac{\mathrm{Cc}^{\prime} \mathrm{o}_{2}-\mathrm{CaO}_{2}}{\mathrm{Cc}^{\prime} \mathrm{o}_{2}-\mathrm{C}_{\mathrm{V}_{2}}}
$$

where

$$
\begin{aligned}
& \mathrm{CaO_{2 }}=1.34(\mathrm{hgb})\left(\mathrm{SaO}_{2}\right)+0.0031 \mathrm{PaO}_{2}, \\
& \mathrm{C} \overline{\mathrm{V}}_{\mathrm{O}_{2}}=1.34(\mathrm{hgb})\left(\mathrm{S}_{\mathrm{O}_{2}}\right)+0.0031 \mathrm{P}_{\mathrm{o}_{2}} \text {, and } \\
& \mathrm{Cc}^{\prime} \mathrm{O}_{2}=1.34(\mathrm{hgb})\left(\mathrm{Sc}^{\prime} \mathrm{O}_{2}\right)+0.0031
\end{aligned}
$$$$
\left(\mathrm{PB}-\mathrm{PH}_{2} \mathrm{O}\right) \mathrm{FIO}_{2}-\mathrm{PaCO}_{2}
$$

Saturations of haemoglobin in arterial, pulmonary arterial, and pulmonary end-capillary blood are $\mathrm{Sa}_{2}, S \overline{\mathrm{v}}_{\mathrm{O}_{2}}$ and $S \mathrm{Sc}^{\prime} \mathrm{o}_{2}$, respectively, and $\mathrm{PB}$ is barometric pressure. The respiratory quotient was assumed equal to $1 ; 1.34$ is the oxygencarrying capacity of haemoglobin in $\mathrm{ml} 0_{2} / \mathrm{gm}$ $\mathrm{hgb}$, and 0.0031 is the oxygen solubility coefficient in $\mathrm{ml} \mathrm{O}_{2}$ /torr. Saturation of oxygen was calculated using the method described by Severinghaus. ${ }^{7} \mathrm{We}$ assumed $\mathrm{Pc}^{\prime} \mathrm{O}_{2}$ to equal the calculated $\mathrm{PAO}_{2}$.

Mean pulmonary-thoracic static compliance (CLT) was calculated using the equation,

$$
\mathrm{CLT}_{\mathrm{L}}=\left(\frac{250 \mathrm{ml}}{\Delta \mathrm{P}_{250}}+\frac{500 \mathrm{ml}}{\Delta \mathrm{P}_{500}}+\frac{750 \mathrm{ml}}{\Delta \mathrm{P}_{750}}\right) \frac{1}{3},
$$

where $\Delta \mathrm{Px}$ is the change in airway pressure induced by the mechanically delivered tidal volume " $x$ " in $\mathrm{ml}$

To produce diffuse bilateral thoracic subcutaneous emphysema, $1200 \mathrm{ml}$ of air were injected slowly ( $2 \mathrm{~min}$ ) through the catheter into the pre-sternal space. After a 10 minute period of equilibration, control measurements were obtained. The animals were then ventilated with a volume ventilator with 75 per cent nitrous oxide with oxygen for 45 minutes; the concentration of inspired oxygen was monitored continuously with an in-line oxygen analyzer. All measurements except cardiac output were repeated every ten minutes until the end of the observation period. Cardiac output was measured at the end of the $\mathbf{4 5}$ minute period. After final measurements, the animals were sacrificed by intravenous injection of potassium chloride and chest roentgenograms were obtained.

The Student t-test for paired data was used to assess the significance of the differences between means before and after exposure to nitrous oxide. All data are reported as means \pm one standard deviation. The minimal level chosen for significance was $\mathrm{p}<0.05$.

\section{RESULTS}

Post-mortem chest roentgenograms confirmed the clinical impression of diffuse bilateral thoracic subcutaneous emphysema and documented the absence of pneumothorax and pneumomediastinum in each animal (Figure 1).

There was no significant change in $\mathrm{Paco}_{2}$; in Qsp/Qt; in subcutaneous, vascular, and peak airway pressures; in thoracic girth; or in lungthorax compliance after the inhalation of nitrous oxide for 45 minutes (Table I). Cardiac output decreased from $3.13 \pm 0.51 \mathrm{l} / \mathrm{min}$ to $2.40 \pm$ $0.62 \mathrm{l} / \mathrm{min}(\mathrm{p}<0.05)$ after ventilation with nitrous oxide for 45 minutes but, when measured again later in four of the animals, had returned to baseline within 10 minutes of discontinuing the nitrous oxide.

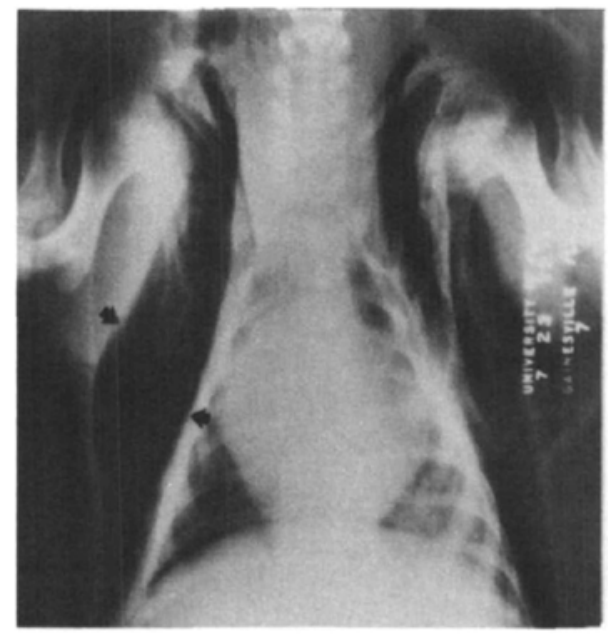

FIGURE 1 To produce diffuse, bilateral thoracic subcutaneous emphysema (arrows), $1200 \mathrm{ml}$ of air were injected subcutaneously anterior to the sternum. 
TABLE I

Cardiorespiratory Variables Before and AfTer Nitrous Oxide (75 PER CENT) INHALation by SWINE With SubCuTANEOUS EMPHYSEMA

\begin{tabular}{|c|c|c|}
\hline \multirow[b]{2}{*}{ Cardiorespiratory variable } & \multicolumn{2}{|c|}{ Nitrous Oxide Inhalation } \\
\hline & Before & After \\
\hline $\begin{array}{l}\text { Paco }_{2} \text { (torr) } \\
\text { Arterial Pressure (torr) } \\
\text { Pulmonary artery pressure (torr) } \\
\text { Pulmonary artery occlusion pressure (torr) } \\
\text { Mean cardiac output (l/min) } \\
\text { Subcutaneous pressure (torr) } \\
\text { Mean compliance (ml/torr) } \\
\dot{Q}_{\mathrm{sp}} / \hat{Q}_{\mathrm{t}} \\
\text { Thoracic girth (cm) } \\
\text { Peak airway pressure (torr) }\end{array}$ & $\begin{aligned} 37.8 & \pm 1.2 \\
130 / 106 & \pm 6 / 4 \\
27 / 15 & \pm 3.6 / 2.2 \\
6 & \pm 1.7 \\
3.13 & \pm 0.51 \\
9.2 & \pm 0.9 \\
19.1 & \pm 2.1 \\
0.06 & \pm 0.01 \\
87.6 & \pm 5.1 \\
16.2 & \pm 2.1\end{aligned}$ & $\begin{aligned} 39.2 & \pm 1.4 \\
129 / 107 & \pm 5 / 5 \\
29 / 17 & \pm 4.2 / 2.3 \\
6 & \pm 1.3 \\
2.40 & \pm 0.62^{*} \\
8.4 & \pm 1.3 \\
18.5 & \pm 3.1 \\
0.06 & \pm 0.02 \\
88.2 & \pm 4.9 \\
17.1 & \pm 2.0\end{aligned}$ \\
\hline
\end{tabular}

*P $<0.05$ compared to the control value.

\section{Discussion}

We studied swine because their skin and subcutaneous tissue resernble those of humans. ${ }^{8}$ A total volume of $1200 \mathrm{ml}\left(48-60 \mathrm{ml} \cdot \mathrm{kg}^{-1}\right)$ of air was chosen for subcutaneous injection because unpublished pilot studies showed that that amount of air produced a physical and radiographic lesion similar to that observed in patients with extensive subcutaneous emphysema. We studied isolated subcutaneous emphysema (i.e., without concomitant pneumomediastinum or pneumothorax) to eliminate the potential confounding effects of pneumothorax and pneumomediastinum. Previous studies of the rate of movement of nitrous oxide into air-containing colon, small intestine, stomach, pleural space, and cerebral ventricle revealed approximate half-times for equilibration of 100 minutes, 95 minutes, 75 minutes, 15 minutes, and six minutes, respectively. ${ }^{2}$ Based on these equilibration times, we arbitrarily chose a 45 minute period of observation as one likely to reveal clinically significant changes in the variables of interest if they were going to occur.

Because of its low blood:gas solubility coefficient, nitrous oxide rapidly saturates highly perfused organs such as the heart and the brain. Equilibration in skin and fat occurs more slowly, but uptake of the drug by these tissues which enclose the subcutaneous space should be substantial within 45 minutes so that further transfer of nitrous oxide into the subcutaneous space should be minimal.

Our failure to find an increase reflected by thoracic girth in the volume of subcutaneous gas after the inhalation of nitrous oxide may be explained in two ways. First, the fatty interface between the subcutaneous tissue and the gas contained within it is relatively avascular so that, in contrast to the tissues of the pleural space, ${ }^{2,3}$ the gut, ${ }^{2}$ the cerebral ventricles ${ }^{4}$ and the middle ear, ${ }^{9}$ the rate of transfer of gas to the subcutaneous tissue may be slower. Secondly, substantial quantities of nitrous oxide may have entered the lax subcutaneous space, but spread so easily cephalad or caudad that no measurable change occurred in thoracic girth.

Since no other measured values changed significantly, it is reasonable to assume that the decrease in cardiac output after 45 minutes of ventilation with 75 per cent nitrous oxide was caused by nitrous-oxide-induced myocardial depression, which is known to occur in swine. ${ }^{10}$

In summary, we found no significant adverse cardiorespiratory effects associated with nitrous oxide inhalation in an animal model of subcutaneous emphysema. The concern articulated by Munson ${ }^{1}$ and Rosenberg et al. ${ }^{5}$ that inhalation of nitrous oxide by subjects with subcutaneous emphysema would be associated with adverse effects is not supported.

The authors gratefully acknowledge the secretarial skills of Ms. Betsy Benson, the editorial assistance of Ms. Lynn Carroll and the helpful suggestions of Dr. Jerome H. Modell.

\section{REFERENCES}

1. Munson, E.S. Transfer of nitrous oxide into body air cavities. Br. J. Anaesth. 46: 202-208 (1974).

2. Eger, E.I. \& SAidman, L.J. Hazards of nitrous oxide anesthesia in bowel obstruction and pneumothorax. Anesthesiology 26: 61-66 (1965). 
3. Chrustian, M.S., Munson, E.S. \& Hamilton, W.K. Pneumothorax following induction of anesthesia. JAMA 209: 1710-1711 (1969).

4. Saidman, L.J. \& Eger, E.L. Changes in cerebrospinal fluid pressure during pneumoencephalography under nitrous oxide anesthesia. Anesthesiology 26: 67-72 (1965).

5. ROSENBERG, M.B., WUNDERLICH, B.K. \& REYNOLDS, R.N. Iatrogenic subcutaneous emphysema during dental anesthesia. Anesthesiology 5]: 80-81 (1979).

6. Milne, B., Katz, H., Rosales, J.K., Assimes, I.K. \& SCHWARTZ, S. Subcutaneous facial emphysema complicating dental anesthesia. Can. Anaesth. Soc. J. 29:71-73 (1982).

7. Severinghaus, J.W. Blood gas calculator. J. Appl. Physiol. 21: 1108-1116 (1966).

8. GRABB, W.C. \& MYERS, B.M. (eds). Skin Flaps. Boston: Little Brown and Co. (1975).

9. Matz, G.J., RatTenborg, C.G. \& Holaday, D.A. Effects of nitrous oxide on middle ear pressure. Anesthesiology 28: 948-950 (1967).

10. BaIlie, M.D., ALWard, C.T., SawYer, D.C., et al. Effect of anesthesia on cardiovascular and renal function in the newborn piglet. J. Pharmacol. Exp. Ther. 208: 298-302 (1979).

\section{RÉSUMÉ}

On connait les effets nocifs de l'inhalation de protoxyde d'azote chez les patients dont les espaces pleuraux ou les cavités ventriculaires cérébrales contiennent déjà de l'air. Nous avons cré́ un modèle animal pour savoir si des effets de même type pouvaient être associé à l'inhalation de protoxyde d'azote lorsque l'espace sous-cutané contient de l'air. Nous avons provoqué un emphysène dans le tissus sous-cutané étendu du porc et mesuré les tensions en oxygène et en gaz carbonique du sang artériel et veineux mêlé, le débit cardiaque, les pressions intra-vasculaires, respiratoires et présternales sous-cutanées, la compliance statique pulmonaire-thoracique totale, et le tour de poitrine avant et après une période de 45 minutes d'inhalation de protoxyde d'azote à 75 pour cent dans l'oxygène. Le débit cardiaque a diminue de $3.13 \pm 0.51 \mathrm{l} / \mathrm{min}$ à $2.40 \pm 0.62 \mathrm{l} / \mathrm{min}(p<0.05)$; toutes les autres valeurs se sont maintenues. Aucune réaction cardio-pulmonaire défavorable n'a suivi le transfert de protoxyde d'azote à l'espace sous-cutane sur ce modele animal. 